\title{
Created in the image of God and sexuality in early-Jewish writings
}

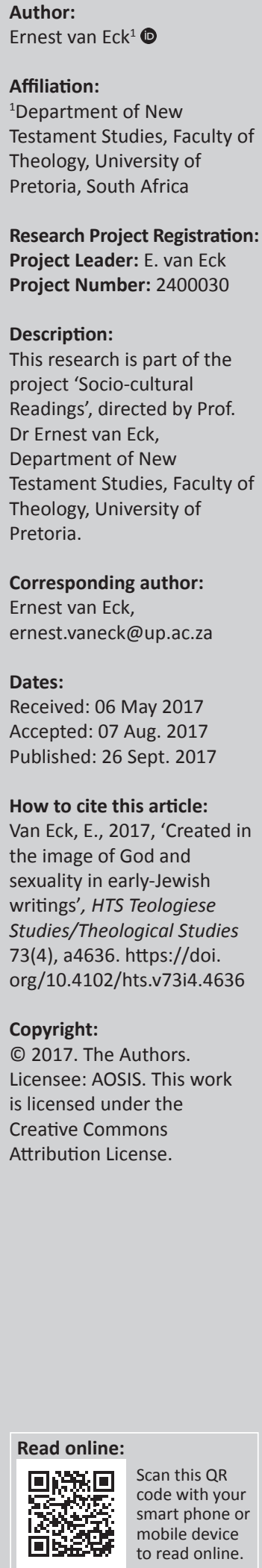

This article pays tribute to the contribution made by Yolanda Dreyer regarding critique on the prevalence of patriarchy in society, as well as her defence of homosexuality as a normal sexual orientation. Taking as point of departure her work on the woman as created in God's image, it is argued that understanding the metaphor 'created in God's image' as referring to rule over all, and not as created as man and woman, has important implications for the relationship between man and woman, as well as the normalisation of relationships between the same sex.

\section{Introduction}

Yolanda Dreyer, for the past two decades, has written extensively on topics such as patriarchy, homosexuality and the (negative power) relationship between man and woman (see Dreyer 2006:445-471; 2007:1493-1521; 2011:1-5). As a precursor to her later publications on especially patriarchy, she published two articles in 2000, focusing on woman as created in the image of God (see Dreyer 2000a:672-696; 2000b:949-972). In these two publications, Dreyer mainly engages with the publication Image of God and gender models in Judaeo-Christian tradition, edited by Kari Elizabeth Børresen. One of the conclusions Dreyer arrives at in her study is that early-Jewish writings prevalently understood the concept or idea of humankind as being created in the image of God as referring to humankind created as man and woman, with maleness as having more importance and in status was seen above the woman. Because Dreyer herself did not engage with the primary early-Jewish sources, mainly depending on the interpretations of these texts by the different contributors in Børresen, the first aim of this article is to trace the metaphor image of God in early-Jewish texts to see if Dreyer indeed is correct in her conclusion regarding the understanding of the metaphor image of God in these texts.

An analysis of these texts, as will be indicated below, firstly indicates that Dreyer is correct in her conclusion that these texts prevalently understand image of God as humankind being created as man and woman, with maleness being more important. These texts, however, go one step further: because God created humankind in his image, as man and woman, only sexual relations between a man and a woman is considered as being natural; all other sexual relations, especially homosex, is depicted as unnatural and taboo.

This conviction still permeates and dominates almost all current debates on homosexual relations; homosex and homoerotic relations are denounced as unnatural, that is, contrary to nature. This argument is normally based on Romans 1:26-27, in which Paul describes homosex as contra to

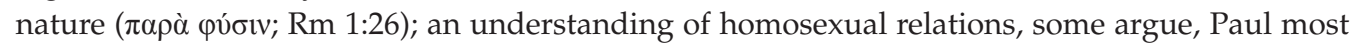
probably advocated because of its widespread acceptance as can be seen from early-Jewish literature (see Van Eck \& Barnard 2013:721-724).

In her study, on the meaning of the image of God in early-Jewish texts, Dreyer comes to a second conclusion, here formulated in the form of a question: What if the metaphor image of God is not understood as being created as man and woman, but as to rule? This suggestion of Dreyer, as will be argued below, has important implications for understanding the relationship between man and woman from a non-patriarchal perspective, as well as relationships between persons of the same sex. These implications, building on the work of Crossan, are spelled out in the latter part of this tribute.

Because early-Jewish literature's conviction that homosex is unnatural is in part a reaction to the prevalent practice of homosex in Roman- and Greek culture, as several scholars have indicated, below attention is firstly given to a description of the practice of homosex and homoerotic relations in Roman and Greek culture. The Jewish reaction to this practice, available in early-Jewish literature, is then described, indicating that the Jewish denunciation of the practice of homosex is 
based on a specific understanding of Genesis 1:26-27. This understanding, as will be indicated, takes as point of departure that humankind was created in God's image, that is, as man and woman. Thus, only sexual relation between the two sexes is seen as natural. This understanding of what is natural led to the understanding that men are superior to women. The tribute, finally, as suggested by Dreyer, interprets the metaphor created in the image of God as to rule over God's creation and not as being created as man and woman. From this perspective, as Dreyer did, homosexual relations is defended as a normal manifestation of sexuality, and the implications of humankind as created in God's image to rule over all, are spelled out.

\section{Homosex and homoerotic relations in the Greco-Roman world}

Roman law rejected homosex amongst its citizens (equals), as well as sexual intercourse with wives of male citizens and unmarried female citizens. Similar acts with men and women of a lower status, however, was acceptable behaviour. A Roman man, therefore, could engage in homosex with own slaves or male prostitutes, with no judgement applied (Loader 2012:83-91). 'Roman males were to be the very opposite of passive: strong, assertive, soldiers, and their sexual capacity one of their weapons of subjugation' (Loader 2012:87, citing Skinner). The assumption prevalent amongst Romans was that:

men normally experience desire for both female and male bodies, and that any given man might act out those desires with persons of one or the other sex ... as long as it was not with male citizens or their wives or unmarried female citizens. (Loader 2012:89, citing Williams)

In the case of same-sex encounters, it was acceptable for the passive partner to enjoy the sexual encounter. Homosex amongst equals, however, was seen as a criminal sexual act and was despised as a Greek disease (Loader 2012:86).

The reason for this is that amongst the Greeks, homosex between equals was not frowned upon. Although pederasty (homosex between adult men and pubescent or adolescent boys) was the most widespread form of same-sex sexual relations amongst the Greeks, homosex between Greek men of equal status (called lovers) was also an acceptable practice.

Herodotus, for example, is of the opinion that the Persians, who cherished luxurious practices of all kinds, welcomed foreign customs. One of these was homosex: 'Their luxurious practices are of all kinds, and all borrowed; the Greeks taught them unnatural vices' (Herodotus, Hist. 1.135 [Godley, LCL]). The Greek words translated by Godley as 'unnatural vices'

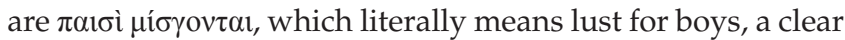
reference to pederasty. Thus, according to Herodotus, pederasty was a custom amongst the Greeks. Athenaeus, in his Deipnosophistae 13:601-605, indicates that this indeed was a custom amongst the Greeks. According to him, pederasty began with the Cretans and from there made its way to Greece (Athenaeus, Deipn. 16.602). Many Greeks, Athenaeus writes, 'wholeheartedly prefer love-affairs with boys to those with women ... The Cretans ... and the inhabitants of Euboean Chalcis became extraordinarily excited about sex with boys' (Athenaeus, Deipn. 16.601 (Olson, LCL]). He continues: ' $[L]$ ove affairs with boys were treated with particular enthusiasm because of the vigor of the young men'. Also, 'when his boyfriend is present, a lover would prefer to suffer absolutely anything rather than get a reputation for cowardice in the boy's eyes' (Athenaeus, Deipn. 16.602 [Olson, LCL]). Athenaeus then goes on and describe how people like king Alexander the Great, king Antigonus and Sophocles 'was partial to boys' (Athenaeus, Deipn. 16.603 [Olson, LCL]) and that Alexander and Sophocles even kissed their boyfriends in public while those being present applauded, clapped and cheered. In spite of being a common practice, Athenaeus, however, still believed that pederasty was an unnatural sex-act, describing it as $\pi \alpha \rho \grave{\alpha}$

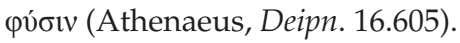

While Herodotus and Athenaeus attest to the common custom of pederasty in Greek culture, Xenophon (Mem. 2.6.28-29) attests to the fact that same-sex relations were also common amongst Greeks 'gentlemen' (Xenophon, Mem. 2.6.28 [Marchant \& Todd, LCL]). In conversing with Critobulus, Xenophon encourages him to pursue a relationship with a gentleman, especially one who will return his love, one who will want Critobulus as much as Critobulus wants him, and one who will please Critobulus as much as Critobulus will want to please him. Although Xenophon calls this kind of relationship a 'friendship', it is clear that these kinds of 'friendships' consisted of a sexual relationship between lovers. Plutarch (Pel. 18) also attests to same-sex relationships between adult Greek men. In describing the fearless army of the Thebans, he attributes their successes on the battlefield to the fact that the Theban army was a sacred band, 'composed of lovers and beloved' (Plutarch, Pel. 18.1 [Perrin, LCL]). Unlike Homer's Nestor, who made the mistake by forming armies in terms of clans and tribes, Plutarch argues that Gorgidas was clever when he formed the army of Thebans by stationing lovers with their beloved; lovers, who are in a friendship, 'are ashamed to play the coward before their beloved, and the beloved before their lovers, and both stand firm in danger to protect each other' (Plutarch, Pel. 18.2-3 [Perrin, LCL]). Clearly, Xenophon and Plutarch here describe same-sex relationships between Greek adult men.

Plato, finally, attests to both pederasty and same-sex relations between adult men as an acceptable practice in Greek culture (Plato, Symp. 177-223). In a conversation on the topic of love, introduced by Eryximachus (Plato, Symp. 177.1), Phaedrus comments that the love between Achilles and his lover Patroclus was admired by the gods because 'there is no sort of valour more respected by the gods than this which comes of love' and that the gods are delighted when 'the beloved is fond of his lover' (Plato, Symp. 180.B [Lamb, LCL]). ${ }^{1}$

1.See also Plato, Phaedrus 227A (Fowler, LCL), where Phaedrus refers to Lysias, who stated that 'favours should be granted rather to the one who is not in love than to the lover'. 
Aristophanes, at his turn, refers to young boys who make friends with men, 'delighting to lie with them and to be clasped in men's embraces' (Plato, Symp. 192.A [Lamb, LCL]). These boy-lovers, Aristophanes continues, are not shameless; they merely do these things 'under the stress of custom' (Plato, Symp. 180.B [Lamb, LCL]).

\section{Homosex and homoerotic relations in Jewish culture}

The acceptable practice of homosex and homoerotic relations amongst the Romans and Greeks was not acceptable in Jewish culture. Apart from, for example, Leviticus 18:22 and 20:13, the practice of homosex is especially denounced in early and later Jewish writings. In Sibylline Oracles 2:73, 3.184-190, 591-600, 760-766, 4.24-36 and 5.166-171, homosex is depicted as impure, unholy, shameless and ungodly behaviour; a transgression of the holy law of the immortal God. The Jews, Sibylline Oracles 3.591-600 states - unlike the Phoenicians, Egyptians, Lins, Persians, Galatians and men of all of Asia and many other nations - honour the eternal God by being mindful of the purity of marriage; they 'do not

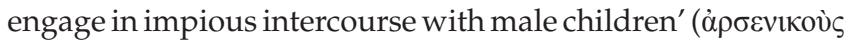

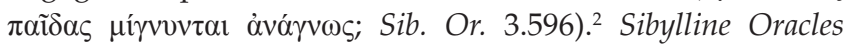
especially criticises Rome for practicing pederasty: 'With you are found adulteries and illicit intercourse with boys ( $\pi \alpha i \delta \omega v$ $\mu \tilde{i} \xi ı \varsigma ~ \alpha ̋ \theta \varepsilon \sigma \mu \rho \varsigma)$, effeminate and unjust, evil city, ill-fated above all' (Sib. Or. :5.166-167). In Rome, Sibylline Oracles continuous, 'male ... have intercourse with male and they ... set up boys

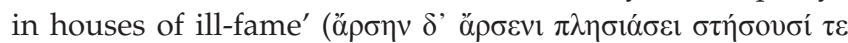

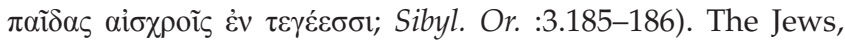
however, refrain from the 'hateful and repulsive abuse of a

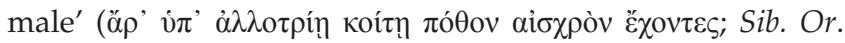
4.34 ), a shameless act typical of the Romans (see also Sib. Or. 4:24-36). Because the Jews worship the Living One ( $\tau \tilde{\omega} \zeta \tilde{\omega} v \tau 1$ $\lambda \alpha ́ \tau \rho \varepsilon v \varepsilon ;$ Sib. Or. 3.763), they are called upon to 'avoid adultery

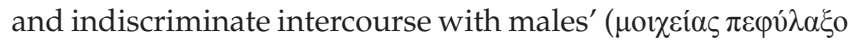

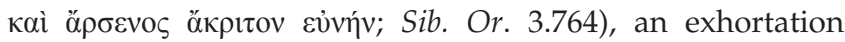
repeated in Sibylline Oracles 2.73: 'Do not practice

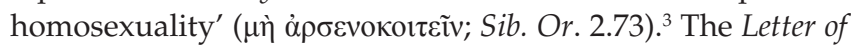
Aristeas, like Sibylline Oracles, refers to homosex to demarcate the Jews from the majority of men from other ethnicities:

The majority of other men defile themselves in their relationships, thereby committing a serious offense, and lands and whole cities take pride in it: they procure the males ... We are quite separated from these practices. (Let. Aris. 1.152) ${ }^{4}$

2 Enoch, an amplification of Genesis 5:21-32, has two references to homosex. In 2 Enoch 9-10, the place created by God for the righteous and the unrighteous are compared with one another. The place for the righteous, which has been prepared as an eternal inheritance, will be inherited by those who averted their eyes from injustice, carried out righteous

2.All translations of Sibylline Oracles are from Collins (1983:357).

3.The exhortation in Sibylline Oracles 2.73, interestingly, is part of a list that calls for

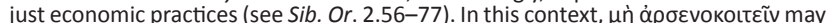
refer to the economic exploitation of young boys who offer homosex.

4.Translation taken from Shutt (1983:23). The Greek texts of the Letter to Aristeas

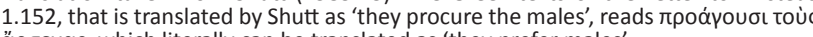
äpoevas, which literally can be translated as 'they prefer males'. judgement, gave bread to the hungry, covered the naked with clothing, helped the injured and the orphans; those who walked without defect before the Lord and worshipped him only (2 En. 9.1). The place for the unrighteous, a frightful place of various tortures, on the other hand, will be inherited by 'those who do not glorify God, who practice on earth the sin which is against nature, which is child corruption in the anus in the manner of Sodom' (2 En. 10.4). ${ }^{5}$ These persons, who are 'sodomite fornicators', will be convicted by God (2 En. 34.1).

Pseudo-Phocylides, a poem written pseudonymously under the name of Phocylides, has as aim to ensure Jews that the best ethics of the Greeks actually agree with the Law and consists of several maxims that contain useful advice for daily life (see Shutt 1983:565). With regards to engaging in homosex, Pseudo-Phocylides has the following advice for Jews: 'Neither commit adultery nor rouse homosexual passion' (Ps.-Phoc. 1.3) and:

do not transgress with unlawful sex the limits set by nature. For even animals are not pleased by intercourse of male with male. And let women not imitate the sexual role of men.' (Ps.-Phoc. 1.190-192)

Pseudo-Phocylides also has advice for parents when it comes to their young boys:

If a child is a boy do not let locks grow on (his) head ... Long hair is not fit for boys. Guard the youthful prime of life of a comely boy, because many rage for intercourse with a man. (PS.-Phoc. $1.210-214)^{6}$

Philo Judaeus of Alexandria, the well-known Jewish author who wrote several works in the first-century $\mathrm{CE}$, makes several references to homosex in his writings. In his De Specialibus Legibus, he refers to wicked men attending the sacred assemblies 'who are afflicted with the disease of effeminacy, men-women, who, having adulterated the coinage of nature, are willingly driven into the appearance

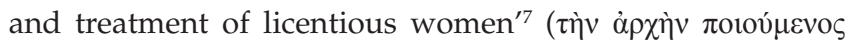

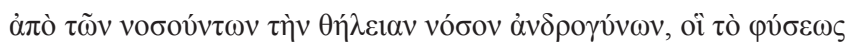

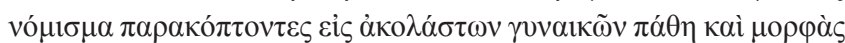

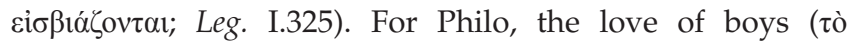
$\pi \alpha 1 \delta \varepsilon \rho \alpha \sigma \tau \varepsilon \tilde{v}$; Leg. 3.37) is a wicked practice and a sin, and his judgement on the passive partners in the act of homosex is quite severe. These men waste away their souls and bodies, have no manly character, their heads are 'conspicuously curled and adorned', their 'faces are smeared with vermilion and paint', their 'eyes are pencilled beneath', and their 'skins are anointed with fragrant perfumes' (Leg. 3.37; Philo 2013:597-598 [Yonge]). Because these men, Philo continues, change their manly characters into that of women ( $\operatorname{Leg} .3: 37)$,

5.Translation taken from Andersen (1983:118)

6.Translation taken from Van der Horst (1983:574, 581).

7.All the translations of Philo's works are taken from Yonge's translation of the complete works of Philo (see Philo 2013:535).

8.See also De Abrahamo 1.136, where Philo has the same argument: These men: 'became accustomed to be treated like women, and in this way engendered among themselves the disease of females, an intolerable evil; for they not only, as to effeminacy and delicacy, became like women in their persons, but they made also effeminacy and delicacy, became like women in their persons, but they made also
their souls most ignoble, corrupting in this way the whole race of man, as far as their souls most ignoble, corrupting
depended on them' (Philo 2013:423) 
they deserve the death penalty, because 'the law commands that the man-woman who adulterates the precious coinage of

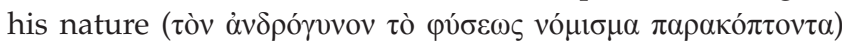
shall die without redemption' (Leg. 3.38). The same should,

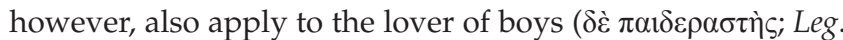
3.39), because they seek pleasure which is contrary to nature

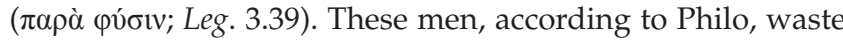
their seed, make cities desolate and make young men waste their prime of life in effeminacy (Leg. 3.39). In his De Abrahamo, Philo again refers to men practicing homosex as acting against nature: 'they discard the laws of nature' ( $\dot{\alpha} \pi \alpha v \chi \varepsilon v i \zeta \zeta_{0 v \sigma l}$

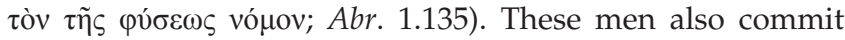
adultery, while lusting for other men because they do not respect their common nature ( 1.135). They, Philo continues:

became accustomed to be treated like women ... engendered among themselves the disease of females, an intolerable evil ... for they not only ... became like women in their persons, but ... also ... corrupting the whole race of man. (Abr. 1.136; Philo 2013:597-598 [Yonge] ${ }^{9}$

Josephus, like Sibylline Oracles, is clear on the practice of homosex amongst the Jews: 'no such thing is permitted

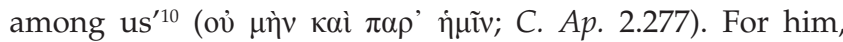
homosex is an 'unnatural and impudent lust, which makes

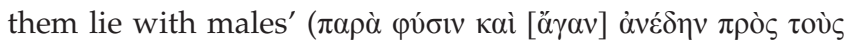

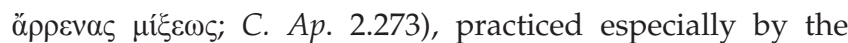
Eleans, Thebans and Greeks. The latter, Josephus argues, see homosex (what Josephus describes as 'sodomite practices';

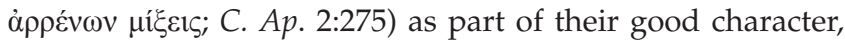
and their apology for this absurd and unnatural pleasure

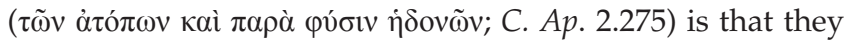
learned it from the gods. In his Antiquitates judaicae 1.194-204, a retelling of Genesis 19, Josephus is clear that God is displeased with such impudent behaviour. The men from Sodom, because they abused themselves with sodomy ( $\tau \grave{\text { ̀े }}$

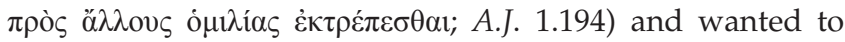
enjoy 'these beautiful boys' (i.e. Lot's guests) by force and

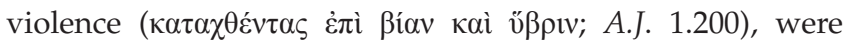
struck with blindness and condemned by God to universal destruction (Josephus, A.J. 1.202). This, Josephus states, is because God was 'much displeased at them, and determined to punish them for their pride' (Josephus, A.J. 1.195).

\section{Unnatural versus natural: The image of God}

From the above, it is clear that in a world dominated by Greco-Roman culture in which homosex and homoerotic relations were accepted, Jewish culture denounced homosex and homoerotic relationships. But for what reason? Above this reason has already been alluded to: it was seen as unnatural or contrary to nature (see again 2 En. 10.4; PS.-Phoc. 1.3; Philo, Leg. 3.39, Abr. 1.135; Josephus, C. Ap. 2.273). Philo,

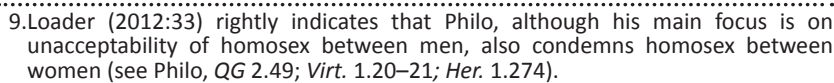
women (see Philo, QG 2.49; Virt. 1.20-21; Her. 1.274).

10.All translations of Josephus are taken from Whiston's translation (see Josephus 1987). the Jewish writer who has written the most extensively on same-sex relations, is very clear on this point. ${ }^{11}$ According to him, God, full of love for mankind, increased 'the natural desire of men and women for a connection together, for the sake of producing children' and detests the unnatural and unlawful commerce of the people of Sodom (Philo, Abr. 1:137). Philo elaborates on this point of view in his Quis rerum divinarum heres sit 1.164 as follows:

It is equality ... that divided the human race into man and woman, making two divisions, unequal in strength, but most perfectly equal for the purpose which nature had principally in view, the generation of a third human being like themselves. For, says Moses, 'God made man; in the image of God created he him; male and female created he them'. [Genesis i. 26] ${ }^{12}$

From the above, the following is clear: For Philo, (1) God created humankind in his image, as man and woman, ${ }^{13}$ (2) only sexual relations between a man and a woman can, therefore, be considered as natural ${ }^{14}$ and (3) the purpose of natural sexual relations is to procreate. ${ }^{15}$ Importantly, for Philo and his Jewish contemporaries, as can be deduced from the quote above (see also QG 2.55-56), Genesis 1:26-2716 served as the basis for their understanding of sexuality. Created in God's image, as man and woman, humankind had to rule over the rest of creation, multiply and fill the earth. Linked with Genesis 2:21-23, the 'Genesis story became the basis for reflection on marriage. Marriage was seen as the context where sexual intimacy had its proper place' (Loader 2013:12). Put differently: The Genesis myth, in which men and women are created in God's image to procreate and rule over the rest of creation, became the basis for reflection on what was considered as natural sexual relations, namely, sexual union between a man and a woman and not between persons of the same sex.

\section{Image of God in early Jewish literature: Created as man and woman}

What did the early Genesis myth intimate? Humankind was created in God's image, but what did it mean? That God created humankind as man and woman or that they had to rule over the rest of creation? Loader (2013) makes the following remark with regards to question of the meaning of

11.See Loader (2012:33) for maybe the best available summary of Philo's point of view on same-sex relations.

12.See also Philo in his Quaestiones et solutiones in Genesin 2.55-56: 'Why was it that God, blessing Noah and his sons, said: 'Increase, and multiply, and replenish the earth, and rule over it; and let your fear and the dread of you be upon all beasts, and upon flying fowls, and upon reptiles, and upon the fishes which I have placed and upon flying fowls, and upon reptiles, and upon the fishes which I have placed
under your hand? [Genesis 9:1] ... And God made man; in the image of God created under your hand? [Genesis 9:1] ... And God made man; in the image of God created
he him; male and female created he them. And God blessed them, and said, Be he him; male and female created he them. And God blessed them,
fruitful, and multiply, and replenish the earth; and be ye lords over it.'

13.See also Philo Legum allegoriae 2.4-5, De plantatione 1.19, De somniis 1.74 , and Quaestiones et solutiones in Genesin 1.4

14.See also Philo in his Quaestiones et solutiones in Genesin 2.49.

15.See also Philo in his Quaestiones et solutiones in Genesin 2.49, and De Abrahamo 1.100-101.

16.Then God said: Let us make mankind in our image, in our likeness, so that they may Then God said: Let us make mankind in our image, in our likeness, so that they may wild animals, and over all the creatures that move along the ground. So God created mankind in his own image, in the image of God he created them; male and female he created them (NIV). 
'created in God's image' for Jews familiar with the creation myth in Genesis:

Some speculate that human beings were made male and female because that is how God is and so they would reflect God's image. As Jews of Jesus' day read it, the similarity was probably seen in the fact that they were to rule as God rules. (p. 10)

Dreyer (2000a:672-696), in her study on women as the image of God, argues to the contrary. According to her, some early-Jewish literature stemming from the time of Jesus attest to the fact that the meaning of 'created in the image of God' first and foremost related to humankind as created by God as man and woman. Moreover, in some of these texts, maleness (Adam) gets preference, while the woman is seen as having less importance, in status below that of Adam. Dreyer (2000a:682-684) gives the following examples:

- In Tobit 8.6 Eve is created for Adam as a helper; the role of the woman is to support the man (Dreyer 2000a:682).

- Jubilees, ${ }^{17}$ a complementary paraphrase on the creation that can be typified as 'primitive history rewritten from the standpoint of the Law' (Wintermute 1983:37), also describes Eve as Adam's helper (Dreyer 2000a:682; see $J u b .3 .4)$.

- In Sibylline Oracles, only Adam is created in the image of God, and Eve not. ${ }^{18}$

- In 2 Enoch (also known as Slavonic Enoch), God commanded his wisdom to create Adam and then creates Eve from one of Adam's ribs. This seems innocent, but the reason for Eve's creation is that death will come to Adam because of Eve's creation. ${ }^{19}$

- In The life of Adam and Eve, a Midrashim on the story of Adam and Eve after being expelled from the garden of Eden, being created in the image of God is mainly reserved as a description for Adam and men. ${ }^{20}$

- In Philo's understanding of the creation, humankind was first created in the image of God. This archetype had male and female characteristics, the ideal human being. In a second phase, God created Adam as androgynous, and from Adam, Eve was created. ${ }^{21}$ Coming from Adam, Eve is of lower status.22

- Josephus, finally, has no reference to the creation of man and woman, replacing it with the creation of the animals as male and female animals, and the task given to Adam

17.Text and translation of Jubilees are taken from Wintermute (1983:52-154).

18. Although not referring to any texts in Sibylline Oracles, Dreyer here most probable refers to Sibylline Oracles 1.23-30, 3.8 and 8.402. In Sibylline Oracles 1.23-30, refers to Sibylline Oracles $1.23-30,3.8$ and 8.402 . In Sibylline Oracles $1.23-30$, Sibylline Oracles 3.8, only men (äv $\theta$ p $\omega \pi$ rot) are described as molded in God's

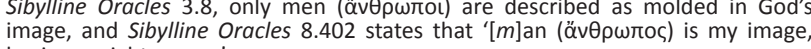
having upright reason'.

19.See 2 Enoch 30.9, 17-18.

20.See, for example, The life of Adam and Eve 13.3, where the devil describes Adam as 'made in the image of God' (see also L.A.E. 14.1-2; 15.2; 56.1). Seth, Adam's son, is also described, by himself, a beast, and by Eve, as God's image (L.A.E. 37.3; 39. 1-2). The translation of The life of Adam and Eve is taken from Johnson (1983: 249-295).

21.See De opificio mundi 1.134, 151-152, and Legum allegoriae 1.31, 92 and 2.4 .

22.See also Loader (2013): 'In his account of the creation of woman Philo cannot help himself in portraying woman as trouble... Much that we read in Philo seems excessively negative about the human body ... and women as a lower form of being driven by passion' (p. 21). to name all the animals. No reference is made by Josephus to the woman. ${ }^{23}$

These examples indicate that the image of God, understood as referring to humankind created as man and woman, was prevalent in Jewish writings. Humankind was created, firstly as man and then as woman, with maleness as having more importance, and therefore in status above the woman.

But there is more to this. As Loader (2013:20) has indicated, the 'argument that man was prior and so superior reflected a widespread assumption about firstly being prior, older being better. The blaming of Eve as first to sin was not new ${ }^{\prime}{ }^{24}$ So Philo (Opif. 1.151-152), who portrays women as trouble, a 'lower form of being driven by passions' (Loader 2013:21). Also, in interpreting God's judgement on the woman in Genesis 3:16-19, Philo argues that '[w]omen's inferiority, including their domination by passions, including sexual passion, stems not from the judgement expressed in Gen 3:16, but from their creation' (Loader 2013:21). In this regard, Loader (2013:23) continues, Apocalypse of Moses 19.3 and 25.34 even goes further: 'Sexual desire is sin. At most, sexual intercourse may be warranted for propagation of species, but sexual passion is here something from the devil'. Or, as put by Sibylline Oracles 1.57-58 and 2 Baruch 56.6 and 73.7, human mortality is the result of sin, makes propagation necessary and so justifies sexual desire (see Loader 2013:22).

To summarise: In Roman culture pederasty and homosex between adult men (under certain circumstances) was acceptable, and in Greek culture pederasty and homosex between adults (lovers) was an acceptable custom. In Jewish culture, as indicated by early-Jewish literature discussed above, homosex and homoerotic relations were not acceptable sexual behaviour; it was seen as impure and ungodly, a transgression of the Law. Also, not practicing homosex demarcated the Jews from the majority of men from other ethnicities. For the Jews, homosex and homoerotic relationships were seen as unnatural, contrary to nature. God created humankind in his image, as man and woman, and therefore, only sexual relations between a man and a woman was natural. Genesis 1:26-27, linked with Genesis 2:21-23, served as the basis for this understanding, as well as the basis for reflection on marriage.

Dreyer's study on women as the image of God indicates that the image of God, understood as referring to humankind created as man and woman, is prevalent in early-Jewish writings. Moreover, in reflecting on man and woman as God's image, early-Jewish literature depicts maleness as having more importance, in status above the woman. Loader, in his study of how early-Jewish literature interpreted the conviction that humankind was created in God's image, that is, created as man and woman, indicates that it led to the

23.Josephus actually does refer to the creation of man: "On the sixth day he created the four-footed beasts, and made them male and female: on the same day he also

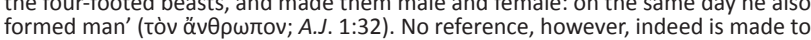
the creation of the woman.

24.As evidence, Loader (2013:20) cites Sirach 25.24; 2 Enoch 30.17, 31.3; Sibylline Oracles 1.42-45; and Apocalypse of Moses 7.2, 10.2, 29.9 and 32.2. 
point of view that man was prior and superior to woman. Eve is blamed for the first sin, and women are trouble, inferior to men, driven by passions. Why? Because this is how woman was created. The first sin led to the second, sexual desire. Finally, the aim of sexual intercourse was only to procreate.

However, the denouncing homosex as unnatural because humankind was created in God's image as man and woman, that what is natural (only sexual relations between men and women in marriage), led to the exploitation of what it means to be woman. Patriarchy and misogyny triumphed; the denunciation of the unnatural led to the denunciation of the natural, that is, femaleness. Fighting the evil of homosex led to another evil: the superiority of the man to the woman.

\section{To rule as image of God}

Dreyer (2000a:672-696), in a discussion of the publication Image of God and gender models in Judaeo-Christian tradition, edited by Kari Elizabeth Børresen, has indicated that contemporary scholars understand, contrary to the classical understanding of humankind created in the image of God as man and woman (as epitomised by the early-Jewish literature discussed above), in an egalitarian way. Bird and Micks, for example, argue that created in the image of God as man and woman indicates equality between the two sexes (see Dreyer 2000a:677). This is also the point of view of Ruether: Genesis $1: 27$, read in its context, does not refer to the relationship between the two sexes, but rather that God created humankind and animal as man and woman (see Dreyer 2000a:678-679).

Bird also, and very importantly, argues that in Genesis 1:27 the metaphor 'image of God' should not be related to humankind as being created as man and woman, but rather to humankind's responsibility, as man and woman, to rule. Humankind, as man and woman, are God's representatives, and both have the same responsibilities. This responsibility, according to Bird, includes all kinds of social relations between people, as well as humankind's relationship with creation (ecology; see Dreyer 2000a:674).

Voluminous works have been written on the meaning of 'to rule as God's image', of which not even a very concise summary of the main arguments regarding the possible meaning of this metaphor can be given here because of space limitations. In one of his recent publications, Crossan (2015) has given a fresh and stimulating interpretation of what it means that humankind, created in God's image, has 'to rule' over all of creation. In his interpretation of 'to rule as image of God', Crossan (2015) indicates that in the creation myth in Genesis 1 the climax of the creation is not humanity, but the Sabbath:

Those priestly authors looked around their Mesopotamianinherited world and saw eight huge chunks of stuff to be identified and organized in God's creation. But they crammed those eight chunks of stuff into not eight, but six days ... Even if eight chunks of stuff exist, they must fit into six days because all of creation must climax with the Sabbath on the seventh day ... [A]ll of creation was crowned with and by the Sabbath. (pp. 76-77)
The final message of Genesis 1, for Crossan (2015:77), therefore is 'Image, Rule, and Sabbath' (emphasis in the original). Firstly, humanity is created in the image or likeness of God (Gn 1:26a, 27), and this status is then immediately identified as having dominion over all in creation (Gn 1:26b, 28 ) - 'that what our divine image means'. Finally, the God whose image we bear is the God of the Sabbath, the God of rest (Crossan 2015:77). Crossan continues: 'We are to rule the Earth for, with, by, and in that Sabbath God. And that is, internally, our human destination, not just, externally, a divine decree or command' (Crossan 2015:77; emphasis in the original).

For Crossan, this implies at least the following: Firstly, God's first gift to humanity is God's own image and likeness, 'precisely what constitutes God as a God of distributive justice', a gracious act of divine justice by which the whole human race has the same identity and destiny (Crossan 2015:77). All receive equally, and as the image of God, all should be treated equally. No distinction, therefore, is to be made in terms of man and woman or status. This, of course, also includes any other distinction that may exist between those created in God's image, for example, ethnicity or sexual orientation - without even the possibility of any kind of discrimination.

Secondly, because all of humanity is created in the image of God, the Sabbath God, all of humanity are supposed to be Sabbath people, and all are to rule over everything and all as Sabbath people. What does this mean? This can be deduced, Crossan argues, from the purpose of the Sabbath as stated in Exodus 23:12 and Deuteronomy 5:12-14, namely to give all alike (householders, children, slaves, immigrants and animals) the same rest; not rest 'for worship of God, but rest as worship of God' (Crossan 2015):

In other words, the Sabbath day as rest in Genesis 1 is both a part and sign of something far deeper than itself - namely, that the crown of creation and the destiny of humanity is distributive justice in a world not our own. The Sabbath day placed distributive justice - where all God's people get a fair share of all God's earth - as the rhythm of time and the metronome of history ...[D]istributive justice is not a command by God but is the character of God. This is why God's first ... distribution to humankind is God's own image and likeness that thereby creates us as agents, stewards, and managers of God's world. (pp. 78-79; emphasis in the original)

The Sabbath year, Crossan continues, should be understood as divine assertion of human subversion. Every seventh year, human subversion of the Torah is to be reversed by the freeing of slaves, the liquidation of debts and the resting of the land. Finally, the purpose of the Sabbath Jubilee is to begin divine assertion all over again; if every Sabbath year cannot accomplish the divine dream of distributive justice, maybe it could be accomplished every 50th year (Crossan 2015:79).

Understanding humankind as created in God's image, not as man and woman, but to rule, clearly brings one to a different 
understanding of what it means to be human, especially with regards to humankind's relationship with other human beings and the creation. If 'to rule' means that we, who are created in God's image, have to rule as Sabbath people created by the Sabbath God, it clearly entails that we are the agents, stewards and managers of God's world. This means that we have the responsibility to make sure that everyone has enough and that everyone is treated equally. Patriarchy and misogyny thus cannot be part of ruling in God's image. As a matter of fact, any kind of discrimination, like that towards those who have other sexual orientations than heterosexuality, is not even a possibility for those who in the image of God rule as God's image.

\section{Conclusion}

In Greek culture, the practice of homosex in the form of pederasty and between adult men of the same status (lovers) was a widespread and acceptable practice. In Roman culture, pederasty and homosex between men and women of a lower status were also judged as acceptable sexual behaviour. Homosex and homoerotic relations, however, were not acceptable behaviour in Jewish culture. The main reason for the strong denunciation of same-sex relations is that it is seen as contrary to nature (unnatural). The Jewish understanding of homosex as unnatural, as especially depicted in early-Jewish literature, is based on a very specific understanding of Genesis 1:26-27. Humankind was created in God's image, as man and woman, and therefore, only sexual relations between a man and a woman are considered as natural. As Dreyer has indicated, the understanding of humankind as man and woman, and so bearing God's image, is not only prevalent in early-Jewish writings but also led the exploitation of what it means to be a woman. These texts ooze of patriarchy and misogyny. In combating one 'evil', another was created.

If one, however, understands humankind as created in God's image as referring first and foremost to rule over God's creation, a different understanding of the relationship between the sexes, and sexual activity, comes to the fore. Firstly, as Dreyer has indicated, it implies equality between man and woman. Secondly, as equals, men and women have the responsibility to rule over creation as Sabbath people. Humanity's internal destination, as Crossan argues, implies that all receives equally, and therefore all has to be treated equally. Crossan calls this as redistributive justice, to rule as the image of God as worship to God, to make sure that all are treated equally and that all has enough. Concomitantly, this implies that any kind of discrimination does not bear witness to what it means to rule as God's image; to taint the image of any human being, is to taint the image of God.

\section{Acknowledgements Competing interests}

The author declares that he has no financial or personal relationships which may have inappropriately influenced him in writing this article.

\section{References}

Andersen, F.I., 1983, '2 (Slavonic apocalypse of ) Enoch (Late First century A.D.) with Appendix', in J.H. Charlesworth (ed.), The Old Testament Pseudepigrapha, Volume 1: Apocalyptic Literature and Testaments, 910221, Yale University Press, New York.

Athenaeus, 2011, Deipnosophistae, vol. VII, transI. S.D. Olson, Harvard University Press, Cambridge. (Loeb Classical Library).

Collins, J.J., 1983, 'Sibylline Oracles (Second century B.C. - Seventh century A.D.)', in J.H. Charlesworth (ed.), The Old Testament pseudepigrapha, Volume 1: Apocalyptic literature and Testaments, pp. 317-472, Yale University Press, New York.

Crossan, J.D., 2015, How to read the Bible and still be a Christian: Struggling with divine violence from Genesis through Revelation, HarperOne, New York.

Dreyer, Y., 2000a, 'Vrou as beeld van God, Deel 1: 'n Historiese ondersoek - Vanaf Genesis tot die Middeleeue', HTS Teologiese Studies 56, 672-696. https://doi org/10.4102/hts.v56i2/3.1764

Dreyer, Y., 2000b, 'Vrou as beeld van God: Vanaf die Reformasie tot die twintigste eeu', HTS Teologiese Studies 56(4), 949-972. https://doi.org/10.4102/hts.v56i4.1800

Dreyer, Y., 2006, 'Heteronormatiwiteit, homofobie en homoseksualiteit -' $n$ roetekaart vir 'n inklusiewe kerk', HTS Teologiese Studies 62(2), 445-471. https://doi. org/10.4102/hts.v62i2.375

Dreyer, Y., 2007, 'Karl Barth's male-female order as asymmetrical theoethics, HTS Teologiese Studies 63(4), 1493-1521. https://doi.org/10.4102/hts.v63i4.265

Dreyer, Y., 2011, 'Women's spirituality and feminist theology: A hermeneutic of suspicion applied to "patriarchal marriage"', HTS Teologiese Studies/Theological Studies 67(3), Art. \#1104, 1-5. https://doi.org/10.4102/hts.v67i3.1104

Herodotus, 1946, Historae, vol. I., transl. A.D. Godley, Harvard University Press, Cambridge. (Loeb Classical Library).

Johnson, M., 1983, 'The life of Adam and Eve (First century B.C.)', in J.H. Charlesworth (ed.), The Old Testament pseudepigrapha, Volume 2: Expansions of the 'Old Testament' and legends, wisdom and philosophical literature, prayers, psalms, odes, fragments of lost Judeo-Hellenistic works, pp. 249-295, Yale University Press, New York.

Josephus, 1987, The complete works of Josephus: Flavius Josephus, Kregel Publications, Grand Rapids, MI.

Loader, W., 2012, The New Testament on sexuality, William B. Eerdmans Publishing Company, Grand Rapids, MI.

Loader, W., 2013, Making sense of sex: Attitudes towards sexuality in early Jewish and Christian literature, William B. Eerdmans Publishing Company, Grand Rapids, MI.

Philo, 2013, The works of Philo, transl. C.D. Yonge, Hendrickson Publishers, Peabody.

Plato, 1939, Lysis, Symposium, Gorgias, vol. V, transI. W.R.M. Lamb, Harvard University Press, Cambridge. (Loeb Classical Library).

Plato, 1953, Euthyphro, Apology, Crito, Phaedo, Phaedrus, vol. I, transl. H.N. Fowler, Harvard University Press, Cambridge. (Loeb Classical Library).

Plutarch, 1917, Plutarch's lives: Agesilaus and Pompey, Pelopidas and Marcellus, vol. V., transl. B. Perrin, Harvard University Press, Cambridge. (Loeb Classical Library).

Shutt, R.J.H., 1983, 'Letter of Aristeas (Third century B.C. - First century A.D.)', in J.H. Charlesworth (ed.), The Old Testament pseudepigrapha, Volume 2: Expansions of the 'Old Testament' and legends, wisdom and philosophical literature, prayers, psalms, odes, fragments of lost Judeo-Hellenistic works, pp. 7-34, Yale University Press, New York.

Van der Horst, P.W., 1983, 'Pseudo-Phocylides (First century B.C. - First century A.D.) in J.H. Charlesworth (ed.), The Old Testament pseudepigrapha, Volume 2: Expansions of the 'Old Testament' and legends, wisdom and philosophical literature, prayers, psalms, odes, fragments of lost Judeo-Hellenistic works, pp. 565-582, Yale University Press, New York.

Van Eck, E. \& Barnard, R., 2013, 'Homoseksualiteit en die sewe klassieke tekste: Antigay of misverstaan?', LitNet Akademies 10, 707-735.

Wintermute, O.S., 1983, 'Jubilees (Second century B.C.)', in J.H. Charlesworth (ed.), The Old Testament pseudepigrapha, Volume 2: Expansions of the 'Old Testament' and legends, wisdom and philosophical literature, prayers, psalms, odes, fragments of lost Judeo-Hellenistic works, pp. 35-42, Yale University Press, New York.

Xenophon, 2013, Memorabilia, Oeconomicus, Symposium, Apology, transl. E.C. Marchant \& O.J. Todd, Harvard University Press, Cambridge. (Loeb Classical Library.) 